\title{
EVALUASI SIFAT KIMIA DAN SENSORI PERMEN JELLY JAMUR TIRAM PUTIH PADA BERBAGAI KONSENTRASI GELATIN
}

\section{EVALUATION OF CHEMICAL PROPERTIES AND SENSORY OF JELLY CANDY OYSTER MUSHROOMS IN VARIOUS GELATIN CONCENTRATIONS}

\author{
Dwi Ardiansyah ${ }^{1}$, Sussi Astuti ${ }^{2}$, dan Susilawati ${ }^{2}$ \\ ${ }^{1}$ Alumni Jurusan Teknologi Hasil Pertanian, Fakultas Pertanian, Universitas Lampung \\ ${ }^{2}$ Jurusan Teknologi Hasil Pertanian, Fakultas Pertanian, Universitas Lampung \\ *Email korespondensi: sussi.astuti@fp.unila.ac.id
}

Diterima 28-04-2021, diperbaiki 25-05-2021, disetujui 29-05-2021

\begin{abstract}
The research objective was to obtain the concentration of gelatin as a gelling agent against the sensory and chemical properties of the best white oyster mushroom jelly candy. The treatments, namely gelatin concentrations of $5 \%, 10 \%, 15 \%, 20 \%, 25 \%$, and $30 \%$ were performed 4 times. The study used a completely randomized block design (RAKL) and further test of the least significant difference. The best gelatin concentration was obtained at $20 \%$ with a jelly candy product that had a somewhat distinctive flavor of white oyster mushrooms with a score of 2.98, chewy texture, score of 3.89, preferred color score of 3.71, overall acceptance preferred score of 3.8. Based on SNI, jelly candy meets the standards, namely water content of $18.27 \%(b b)$, ash content of $0.25 \%(b b)$, reducing sugar $0.28 \%(b b)$, and sucrose content of $51.33 \%(b b)$.
\end{abstract}

Keywords: jelly candy, gelatin, white oyster mushroom

\begin{abstract}
ABSTRAK
Tujuan penelitian adalah mendapatkan konsentrasi gelatin sebagai bahan pembentuk gel terhadap sifat sensori dan kimia permen jelly jamur tiram putih terbaik. Perlakuan yaitu konsentrasi gelatin 5\%, $10 \%, 15 \%, 20 \%, 25 \%$, dan 30\% dilakukan 4 kali. Penelitian menggunakan Rancangan Acak Kelompok Lengkap (RAKL) dan uji lanjut Beda Nyata Terkecil. Konsentrasi gelatin terbaik diperoleh pada 20\% dengan produk permen jelly yang memiliki flavor agak khas jamur tiram putih dengan skor 2,98, tekstur kenyal skor 3,89, warna disukai skor 3,71, penerimaan keseluruhan disukai skor 3,83. Berdasarkan SNI, permen jelly memenuhi standar yaitu kadar air sebesar 18,27\% (bb), kadar abu 0,25\% (bb), gula reduksi 0,28\% (bb), dan kadar sukrosa 51,33\% (bb).
\end{abstract}

Kata kunci: permen jelly, gelatin, jamur tiram putih

\section{PENDAHULUAN}

Sebagai salah satu sayuran yang dikenal menyehatkan karena kadungan komponen aktif di dalamnya, kandungan nutrisi jamur tiram putih (Pleurotus ostreatus) juga tergolong lengkap. Menurut Alexs (2011), kandungan gizi jamur tiram putih per $100 \mathrm{~g}$ bahan adalah protein sebesar $27 \mathrm{~g}$, karbohidrat sebesar $58 \mathrm{~g}$, lemak sebesar 1,6g, abu sebesar 9,3g, thiamin sebesar $4,8 \mathrm{mg}$, riboflavin sebesar 
4,7 mg, niacin sebesar 108,7 mg, dan kalsium sebesar 37,9 mg. Kandungan serat jamur tiram putih sebesar 11,5g dilaporkan dapat membantu proses pencernaan, serta menyebabkan penurunan berat badan, kadar gula darah, dan kolesterol.

Kelemahan jamur tiram putih sebagaimana jenis sayuran lainnya, adalah dalam waktu satu hari setelah panen akan mengalami penurunan mutu menjadi layu, warna berubah gelap, tektur lunak diikuti perubahan citarasa sehingga menjadi tidak layak dikonsumsi. Proses pengawetan yang dilakukan dengan menyimpan dalam plastik polietilen pada refrigerator suhu $4-8^{\circ} \mathrm{C}$ mampu memperpanjang umur simpan selama 3-5 hari. Upaya yang dilakukan untuk memanfaatkannya adalah dengan diversifikasi produk olahan seperti permen jelly.

Bahan baku pembuatan permen jelly antara lain sari buah, air, dan bahan pembentuk gel dengan tampilan produk jernih transparan dan kenyal. Dari berbagai macam bahan pembentuk gel permen jelly, gelatin adalah salah satunya. Karim dan Bhat (2008) menyatakan bahwa industri pangan memanfaatkan gelatin sebagai bahan pengikat, penstabil, pengental, pembentuk gel, pengemulsi, perekat, dan pembungkus makanan yang dapat dimakan. Sifat khas dari gelatin antara lain kekuatan gel, titik leleh dan viskositas yang sangat penting dalam produk pangan olahan (Liu et al., 2009). Pemanfaatan gelatin pada berbagai produk permen jelly dengan bahan baku yang berbeda telah dilakukan oleh Rahmi et al. (2012) berbahan bunga rosella, susu kambing (Eletra et al., 2013), nanas (Basuki et al., 2014), sari brokoli (Nurismanto et al., 2015), dan wortel (Sriyono et al. 2017).

Informasi pemanfaatan gelatin dalam pembuatan permen jelly jamur tiram putih belum dilaporkan, sehingga tujuan penelitian adalah mendapatkan konsentrasi gelatin dengan sifat kimia dan sensori terbaik yang menghasilkan permen jelly jamur tiram putih sesuai Standar Nasional Indonesia (SNI 3547.2008).

\section{Bahan dan Alat}

BAHAN DAN METODE

Bahan berupa jamur tiram putih (Pleurotus ostreatus) segar, gelatin, sukrosa, air. Bahan kimia yaitu $\mathrm{KI}, \mathrm{H}_{2} \mathrm{SO} 4$, larutan Luff-Schrool, Na2CO3, Pb-Asetat, $\mathrm{H}_{2} \mathrm{SO} 4$, dan Na-Thiosulfat. Peralatan penelitian adalah alat-alat untuk pembuatan permen jelly, serta untuk analisis kimia dan uji sensori.

\section{Pelaksanaan Penelitian}

Perlakuan faktor tunggal yaitu 6 taraf konsentrasi gelatin 5\% (P1), 10\% (P2), 15\% (P3), 20\% (P4), 25\% (P5), dan 30\% (P6). Pada pembuatan bubur jamur tiram putih, ditimbang $50 \mathrm{~g}$ badan jamur, dibersihkan, ditambah air $250 \mathrm{ml}$ dan direbus 5 menit suhu $100 \circ \mathrm{C}$, ditiriskan dan diblender dengan penambahan $100 \mathrm{ml}$ air hingga menjadi bubur. Permen jelly jamur tiram dibuat dengan memasukkan dalam wajan teflon $100 \mathrm{ml}$ bubur jamur dan $100 \mathrm{~g}$ sukrosa, dimasak 5 menit, ditambah gelatin sesuai perlakuan. Penambahan gelatin dihitung berdasarkan volume bubur jamur (b/v) yang dilarutkan pada $75 \mathrm{ml}$ air hangat, dimasak dan diaduk hingga mengental selama 5 menit. Selanjutnya dituang ke loyang (tebal $1 \mathrm{~cm}$ ), didiamkan 20 jam pada suhu 25oC, dipotong ukuran $1 \times 1 \mathrm{~cm}$, lalu diamati. Perlakuan dilakukan menggunakan Rancangan Acak Kelompok Lengkap dalam 4 ulangan, data dianalisis menggunakan analisis ragam dan dilakukan uji lanjut Beda Nyata Terkecil. Pengamatan dilakukan terhadap kadar air, kadar abu (AOAC, 2012), serta sifat sensori flavor, warna, keken yalan, dan penerimaan keseluruhan oleh 20 orang panelis semi terlatih (Setyaningsih et al., 2010). Parameter flavor dan kekenyalan diuji skoring, warna dan penerimaan keseluruhan diuji hedonik. Untuk flavor sangat khas jamur tiram diberi skor 5, khas jamur tiram skor 4, agak khas jamur tiram skor 3, tidak khas jamur tiram skor 2, dan sangat tidak khas jamur tiram skor 1. Untuk kekenyalan, kriteria sangat kenyal diberi skor 5, kenyal skor 4, agak kenyal skor 3, tidak kenyal skor 2, dan 
sangat tidak kenyal skor 1. Untuk warna dan penerimaan keseluruhan, kriteria sangat suka diberi skor 5, suka skor 4, agak suka skor 3, tidak suka skor 2, dan sangat tidak suka skor 1 . $\mathrm{Pada}$ perlakuan terbaik diamati kadar gula reduksi dan kadar sukrosa (AOAC, 2012).

\section{HASIL DAN PEMBAHASAN}

\section{Flavor}

Konsentrasi gelatin berpengaruh nyata terhadap flavor permen jelly dengan skor flavor berkisar antara 2,89-3,18 (agak khas jamur tiram putih) (Tabel 1).

Tabel 1. Flavor permen jelly jamur tiram putih

\begin{tabular}{lcc}
\hline Perlakuan & Nilai Tengah & Notasi \\
\hline P1 (Gelatin 5\%) & 3,18 & $\mathrm{a}$ \\
P2 (Gelatin 10\%) & 3,10 & $\mathrm{ab}$ \\
P3 (Gelatin 15\%) & 2,99 & $\mathrm{~b}$ \\
P4 (Gelatin 20\%) & 2,98 & $\mathrm{bc}$ \\
P5 (Gelatin 25\%) & 2,94 & $\mathrm{c}$ \\
P6 (Gelatin 30\%) & 2,89 & $\mathrm{c}$ \\
\hline
\end{tabular}

BNT $0,05=0,124$

Keterangan : Huruf yang sama artinya tidak berbeda nyata pada uji BNT 5\%

Berdasarkan Tabel 1, perlakuan penambahan gelatin 5\% (P1) tidak berbeda nyata dengan gelatin $10 \%(\mathrm{P} 2)$, namun berbeda nyata dengan perlakuan penambahan gelatin 15\% (P3), 20\% (P4), $25 \%$ (P5), dan 30\% (P6). Perlakuan P4 berbeda dengan $\mathrm{P} 1$, namun tidak berbeda dengan P2, P3, P5 dan P6. Skor rata-rata flavor tertinggi sebesar 3,18 pada perlakuan P1 dengan konsentrasi gelatin $5 \%$ dan skor terendah sebesar 2,89 pada perlakuan P6 konsentrasi gelatin 30\% (agak khas jamur tiram putih).

Perbedaan flavor permen jelly disebabkan banyaknya konsentrasi gelatin yang digunakan pada masing-masing perlakuan. Flavor permen jelly jamur tiram putih akan tertutupi oleh flavor gelatin pada penambahan gelatin yang semakin tinggi. Karim dan Bath (2008) menyatakan bahwa hidrokoloid gelatin merupakan polimer larut air, memiliki peran sebagai bahan pengental dan pembentuk gel. Menurut Piccone et al. (2011), peningkatan konsentrasi hidrokoloid pada bahan makanan akan meningkatkan volume produk, namun mengurangi flavor asli produk tersebut.

Asam amino esensial lengkap yang terkandung dalam jamur tiram putih diantaranya leusin, isoleusin, valin, triptofan, lisin, threonin, fenilalanin, metionin dan histidin (Martawijaya \& Nurjayadi, 2010). Binsi et al. (2009) melaporkan kadar protein gelatin kering dari kulit ikan kakap besar sebesar 94,6\% dan kadar air $4,2 \%$, dengan profil asam amino gelatin tertinggi yaitu glisin. Menurut Hamed et al. (2016), ekstraksi gelatin secara kimiawi dapat dilakukan dengan pelarut asam maupun basa, sedangkan secara biokimiawi menggunakan enzim. Khiari et al. (2013) menyatakan bahwa perlakuan awal berpengaruh terhadap komposisi dan sifat fungsional gelatin yang diekstraksi. Dilaporkan bahwa pada gelatin yang diekstrak dari tulang ikan mackerel dan diolah secara kimiawi lebih tinggi kandungan asam amino prolin dan hidroksiprolinnya dibanding secara enzimatis. Menurut Mariod dan Adam (2013), kekuatan gel, viskositas, dan titik leleh gelatin tergantung pada distribusi berat molekul dan komposisi asam amino, serta keberadaan asam amino prolin dan hidroksiprolin. Gelatin yang kandungan asam aminonya lebih tinggi juga cenderung lebih tinggi kekuatan gel dan titik lelehnya.

Penambahan konsentrasi gelatin menyebabkan meningkatnya kadar asam amino permen jelly tersebut. Menurut Zuhra (2006), perlakuan pemanasan pada bahan 
yang mengandung asam amino dengan adanya air menyebabkan asam amino dapat berikatan silang dan merubah flavor bahan. Dari data flavor permen jelly, semakin tinggi penambahan konsentrasi gelatin mengakibatkan timbulnya flavor asing.

\section{Kekenyalan}

Konsentrasi gelatin berpengaruh sangat nyata terhadap kekenyalan permen jelly jamur tiram putih dengan skor kekenyalan berkisar antara 2,97-4,12 (agak kenyal - kenyal) (Tabel 2).

Tabel 2. Kekenyalan permen jelly jamur tiram putih

\begin{tabular}{lcc}
\hline Perlakuan & Nilai Tengah & Notasi \\
\hline P6 (Gelatin 30\%) & 4,12 & $\mathrm{a}$ \\
P5 (Gelatin 25\%) & 3,99 & $\mathrm{a}$ \\
P4 (Gelatin 20\%) & 3,89 & $\mathrm{ab}$ \\
P3 (Gelatin 15\%) & 3,76 & $\mathrm{bc}$ \\
P2 (Gelatin 10\%) & 3,50 & $\mathrm{~cd}$ \\
P1 (Gelatin 5\%) & 2,97 & $\mathrm{e}$ \\
\hline
\end{tabular}

BNT $0,05=0,314$

Keterangan : Huruf yang sama artinya tidak berbeda nyata pada uji BNT 5\%

Berdasarkan Tabel 2, konsentrasi gelatin $30 \%$ (P6) tidak berbeda nyata dengan $25 \%$ (P5) dan 20\% (P4), namun berbeda nyata dengan $15 \%(\mathrm{P} 3), 10 \%(\mathrm{P} 2)$ dan 5\% (P1). Kekenyalan permen jelly jamur tiram putih tertinggi pada skor ratarata 4,12 (kenyal) konsentrasi gelatin 30\% (P6), skor rata-rata terendah 2,97 (agak kenyal) pada konsentrasi gelatin 5\% (P1), sehingga kekenyalan permen jelly dipengaruhi oleh perbedaan konsentrasi gelatin. Gelatin bersifat reversible, yaitu apabila dipanaskan akan terbentuk cairan dan sewaktu didinginkan akan terbentuk gel, yang dibutuhkan dalam pembuatan permen jelly.

Herawati (2018) menyatakan bahwa kemudahan dalam penyerapan air dan pembentukan gel merupakan karakteristik utama hidrokoloid. Dilaporkan bahwa elastisitas dan kekakuan merupakan sifat gel sebagaimana padatan. Menurut Mariod dan Adam (2013), salah satu faktor terpenting dalam pembentukan gel yang mempengaruhi kekuatan dan stabilitas gel adalah konsentrasi gelatin yang ditambahkan dalam produk pangan, salah satunya pada produk permen jelly. Apabila konsentrasi gelatin yang ditambahkan terlalu rendah, tekstur permen jelly yang terbentuk akan lunak, sedangkan konsentrasi gelatin yang terlalu tinggi menyebabkan tekstur permen jelly menjadi kenyal. Gel terbentuk akibat ikatan hidrogen antar molekul gelatin. Kekuatan gel gelatin yang dipengaruhi oleh panjang rantai asam amino akan mempengaruhi elastisitas produk yang dihasilkan. Karena misel yang dibentuk gelatin kuat, maka kekuatan gel semakin meningkat dengan semakin panjangnya rantai asam amino gelatin. Nguyen et al. (2017) menyatakan bahwa kandungan protein mempengaruhi kekuatan jaringan pada saat pembentukan gel dan membuat produk menjadi lebih kenyal.

Salah satu fisik gelatin yang sangat penting adalah kekuatan gel. Gelatin harus memiliki sifat dapat berubah wujud dari cairan menjadi padatan atau mengubah sol menjadi gel yang bersifat reversible. Molekul-molekul gelatin yang dipanaskan dapat mengembang sehingga terbentuk gel (Taufik, 2011; Darwin et al., 2018). Pembentukan gel (gelasi) merupakan suatu fenomena penggabungan atau pengikatan silang rantai-rantai polimer membentuk jalinan tiga dimensi yang kontinyu, sehingga dapat menangkap air di dalamnya menjadi struktur yang kompak dan kaku, yang tahan terhadap aliran di bawah tekanan. Gelatin akan menjadi lebih kental dan selanjutnya 
terbentuk gel pada saat solid dari gelatin menjadi dingin (Funami, 2011).

Gotthoffer (2012) berpendapat gelatin berfungsi mengubah tekstur dengan cara membentuk jaringan dari molekul-molekul dalam bentuk sol yang telah menyerap air. Tiap partikel gelatin akan menyerap air sehingga terbentuk sol yang berbentuk cairan. Ketika didinginkan, molekul gelatin yang sebelumnya berbentuk gulungan kompak dalam bentuk cairan akan terurai membentuk ikatan silang antar molekul lainnya yang berdekatan sehingga membentuk gel.

\section{Warna}

Warna permen jelly jamur tiram putih dengan skor 3,19-3,71 (agak suka - suka), sangat nyata dipengaruhi konsentrasi gelatin (Tabel 3).

Tabel 3. Warna permen jelly jamur tiram putih

\begin{tabular}{lcc}
\hline Perlakuan & Nilai Tengah & Notasi \\
\hline P4 (Gelatin 20\%) & 3,71 & $\mathrm{a}$ \\
P5 (Gelatin 25\%) & 3,55 & $\mathrm{a}$ \\
P3 (Gelatin 15\%) & 3,54 & $\mathrm{ab}$ \\
P6 (Gelatin 30\%) & 3,44 & $\mathrm{~b}$ \\
P2 (Gelatin 10\%) & 3,43 & $\mathrm{bc}$ \\
P1 (Gelatin 5\%) & 3,19 & $\mathrm{~d}$ \\
\hline
\end{tabular}

BNT $0,05=0,216$

Keterangan : Huruf yang sama artinya tidak berbeda nyata pada uji BNT 5\%

Berdasarkan Tabel 3, perlakuan penambahan gelatin 20\% (P4) tidak berbeda nyata pada gelatin $25 \%(\mathrm{P} 5)$ dan $15 \%(\mathrm{P} 3)$, namun berbeda nyata dengan $30 \%$ (P6), $10 \%$ (P2) dan 5\% (P1). Konsentrasi 20\%-P4 (suka) memberikan skor rata-rata warna tertinggi sebesar 3,71, konsentrasi 5\% (P1)agak suka memberikan skor terendah sebesar 3,19.

Perbedaan konsentrasi gelatin menyebabkan perubahan warna permen jelly. Warna permen jelly yang bening dan transparan terlihat pada penambahan gelatin konsentrasi rendah, sedangkan warna kecoklatan dihasilkan dari konsentrasi gelatin yang terlalu tinggi, karena gelatin berwarna agak kekuningan. Semakin banyak gelatin yang ditambahkan, permen jelly menghasilkan warna yang semakin gelap (kecoklatan). Warna kecoklatan disebabkan oleh reaksi Maillard, yaitu reaksi pencoklatan nonenzimatik yang melibatkan asam amino dan gugus karbonil terutama gula pereduksi. Semakin banyak gelatin yang digunakan, maka semakin banyak asam amino yang akan bereaksi dengan gula pereduksi dan terjadi reaksi Maillard. Reaksi Maillard tidak membutuhkan suhu tinggi, namun laju reaksi akan meningkat tajam pada suhu tinggi dan menyebabkan pencoklatan semakin cepat terjadi.

Menurut BeMiller dan Whistler dalam Damodaran dan Parkin (2017), reaksi Maillard terjadi pada dua tahap yaitu tahap reaksi awal dan reaksi lanjutan. Pada reaksi awal terjadi kondensasi antara gugus karbonil dari gula pereduksi dengan gugus amina bebas dari asam amino dalam rangkaian protein. Hasil kondensasi yang kehilangan molekul air akan berubah menjadi basa schiff dan akan tersiklisasi oleh Amadori rearrangement membentuk senyawa 1-amino-1-deoksi-2-ketosa. Penurunan ketersediaan lisin menyebabkan senyawa 1 - amino-1-deoksi-2-ketosa atau senyawa amadori akan terdegradasi menghasilkan produk intermediate 3-dioksi dan metal-alfa-dikarbonil yang bereaksi dengan senyawa amina dalam bahan pangan membentuk pigmen melanoidin yang berwarna kecoklatan.

\section{Penerimaan Keseluruhan}

Penerimaan keseluruhan permen jelly jamur tiram putih dengan skor 2,83-3,83 (agak suka - suka) (Tabel 4) dipengaruhi sangat nyata oleh konsentrasi gelatin. 
Tabel 4. Penerimaan keseluruhan permen jelly jamur tiram putih

\begin{tabular}{lcc}
\hline Perlakuan & Nilai Tengah & Notasi \\
\hline P4 (Gelatin 20\%) & 3,83 & $\mathrm{a}$ \\
P3 (Gelatin 15\%) & 3,61 & $\mathrm{ab}$ \\
P2 (Gelatin 10\%) & 3,48 & $\mathrm{~b}$ \\
P5 (Gelatin 25\%) & 3,47 & $\mathrm{~b}$ \\
P6 (Gelatin 30\%) & 3,38 & $\mathrm{bc}$ \\
P1 (Gelatin 5\%) & 2,83 & $\mathrm{~d}$ \\
\hline
\end{tabular}

BNT $0,05=0,262$

Keterangan: Huruf yang sama artinya tidak berbeda nyata pada uji BNT 5\%

Berdasarkan Tabel 4, perlakuan penambahan konsentrasi gelatin $20 \%$ (P4) tidak berbeda nyata pada penambahan konsentrasi gelatin $15 \% \quad(\mathrm{P} 3)$, namun berbeda nyata dengan penambahan konsentrasi gelatin 10\% (P2), 25\% (P5), $30 \%$ (P6) dan 5\% (P1). Permen jelly jamur tiram putih memiliki skor penerimaan keseluruhan tertinggi 3,83 pada konsentrasi gelatin 20\% (P4)-suka, sedangkan skor terendah agak suka-2,83 pada konsentrasi $5 \%(\mathrm{P} 1)$.

Skor penerimaan keseluruhan menunjukkan permen jelly konsentrasi gelatin 20\% (P4) adalah yang paling disukai panelis. Hal ini diduga konsentrasi tersebut menghasilkan flavor agak khas jamur tiram, kenyal, dan warna kuning cenderung jernih. Produk lain yang menghasilkan penerimaan keseluruhan disukai sampai agak suka berturut-turut adalah permen jelly konsentrasi gelatin $15 \%$ (P3), 10\% (P2), 25\% (P5), 30\% (P6), dan $5 \%$ (P1). Produk P2, P3, dan P5 menghasilkan skor penerimaan keseluruhan yang termasuk dalam kriteria suka, sedangkan permen produk P6 dan P1 menghasilkan skor penerimaan keseluruhan kriteria agak suka. Permen jelly P6 memiliki skor penerimaan keseluruhan kriteria agak disukai karena tekstur terlalu kenyal mendekati keras dengan warna kecoklatan, sedangkan permen jelly jamur tiram putih P1 memiliki skor penerimaan keseluruhan terendah dengan kriteria agak disukai, tekstur agak lunak, dan warna terlalu jernih.

\section{Kadar Air}

Kadar air permen jelly berkisar 1224\% (Tabel 5), dipengaruhi sangat nyata oleh konsentrasi gelatin.

Tabel 5. Kadar air permen jelly jamur tiram putih

\begin{tabular}{lcc}
\hline Perlakuan & Nilai Tengah (\%) & Notasi \\
\hline P6 (Gelatin 30\%) & 24,35 & $\mathrm{a}$ \\
P5 (Gelatin 25\%) & 21,90 & $\mathrm{~b}$ \\
P4 (Gelatin 20\%) & 18,27 & $\mathrm{c}$ \\
P3 (Gelatin 15\%) & 16,28 & $\mathrm{~d}$ \\
P2 (Gelatin 10\%) & 14,48 & $\mathrm{e}$ \\
P1 (Gelatin 5\%) & 11,76 & $\mathrm{f}$ \\
\hline
\end{tabular}
BNT $0,05=0,600$

Keterangan: Huruf yang sama artinya tidak berbeda nyata pada uji BNT 5\%

Berdasarkan Tabel 5, kadar air konsentrasi gelatin 30\% (P6) berbeda dengan konsentrasi gelatin 25\% (P5), 20\% (P4), 15\% (P3), 10\% (P2) dan 5\% (P1). Kadar air permen jelly tertinggi sebesar
24,35\% dihasilkan gelatin 30\% (P6), kadar air terendah sebesar $11,75 \%$ dihasilkan gelatin 5\% (P1). Penambahan konsentrasi gelatin menyebakan peningkatan kadar air permen jelly. Hal ini karena dalam proses 
pembuatan permen jelly, gelatin merupakan bahan pembentuk gel yang mampu mengikat air (Nelwan, 2015).

Menurut Karim dan Bath (2008), pembentukan gel merupakan suatu fenomena penggabungan atau pengikatan silang rantai-rantai polimer membentuk jalinan tiga dimensi yang kontinyu, sehingga dapat menangkap air di dalamnya menjadi struktur yang kompak dan kaku yang tahan terhadap aliran di bawah tekanan. Pada saat solid dari gelatin mendingin, maka akan menjadi lebih kental dan selanjutnya terbentuk gel. Gelatin mempunyai sifat reversibel yaitu apabila dipanaskan akan mencair dan membentuk sol. Jika didinginkan sol akan berubah menjadi gel dan gel tersebut lebih mirip padatan dari pada cairan. Pada saat dilakukan pemasakan pada suhu $90^{\circ} \mathrm{C}$, maka panas akan membuka ikatan-ikatan pada molekul gelatin. Molekul-molekul tersebut mulai mengurai dan terjadi ikatan-ikatan silang antara molekulmolekul yang berdekatan sehingga terbentuk satu jaringan molekul-molekul yang saling bertautan sehingga menyebabkan air yang semula bebas mengalir menjadi terperangkap di dalam struktur tersebut (Gotthoffer, 2012).

Menurut Gotthoffer (2012), jika gelatin dipanaskan dengan penambahan air, maka akan terjadi ikatan menyilang pada kedua rantai peptida gelatin. Ikatan menyilang terjadi antara gugus karboksil dari asam amino dan distabilkan dengan ikatan hidrogen. Komposisi asam amino mempengaruhi kemampuan gelatin untuk mengikat air (Leward et al., 2000). Semakin tinggi konsentrasi gelatin yang ditambahkan pada permen jelly, semakin banyak asam amino yang akan mengikat air sehingga mengurangi jumlah air yang terbebas.

Penambahan konsentrasi gelatin pada pembuatan permen jelly mempengaruhi peningkatan kadar air produk tersebut. Permen jelly dengan kadar air tertinggi sebesar 24,35\% dihasilkan gelatin $30 \%$. Pada konsentrasi gelatin $30 \%$ dan $25 \%$, kadar air permen jelly tersebut tidak memenuhi standar mutu SNI 3547.2-2008 karena kadar airnya di atas 20\%. Konsentrasi gelatin 5\%, 10\%, $15 \%$, dan $20 \%$ menghasilkan kadar air permen jelly jamur tiram yang memenuhi standar mutu jelly SNI 3547.2-2008 yaitu kurang dari $20 \%$.

Nilai kadar air ini sejalan dengan Nelwan (2015) pada permen jelly sari buah pala, bahwa semakin tinggi konsentrasi gelatin, kadar air permen jelly sari buah pala menghasilkan kadar air semakin tinggi. Laporan Rahmi (2012) tentang permen jelly bunga rosella, peningkatan kadar air produk juga dipengaruhi banyaknya jumlah gelatin yang ditambahkan. Produk dengan kadar air tertinggi pada penambahan gelatin $20 \%$ sebesar 32,09\%, sedangkan konsentrasi gelatin $10 \%$ menghasilkan kadar air $29,68 \%$.

\section{Kadar Abu}

Kadar abu permen jelly jamur tiram putih antara 0,12-0,47 \% (Tabel 6) dipengaruhi nyata oleh konsentrasi gelatin.

Berdasarkan Tabel 6, kadar abu permen jelly gelatin $30 \%$ berbeda dengan gelatin $25 \%, 20 \%, 15 \%, 10 \%$, dan $5 \%$. Kadar abu produk permen jelly tertinggi sebesar $0,46 \%$ dihasilkan gelatin $30 \%$, sedangkan kadar abu terendah 0,12\% dihasilkan gelatin 5\%. Semakin tinggi penambahan konsentrasi gelatin, kadar abu semakin meningkat. Peningkatan kadar abu permen jelly tersebut disebabkan mineral dalam gelatin dan jamur tiram putih. Kadar abu adalah campuran komponen anorganik pada bahan pangan yang tidak terbakar. Kadar abu permen tersebut memenuhi standar mutu jelly SNI 3547.2-2008 yaitu kurang dari $3 \%$. 
Tabel 6. Kadar abu permen jelly jamur tiram putih

\begin{tabular}{lcc}
\hline Perlakuan & Nilai Tengah (\%) & Notasi \\
\hline P6 (Gelatin 30\%) & 0,47 & $\mathrm{a}$ \\
P5 (Gelatin 25\%) & 0,35 & $\mathrm{~b}$ \\
P4 (Gelatin 20\%) & 0,25 & $\mathrm{c}$ \\
P3 (Gelatin 15\%) & 0,21 & $\mathrm{~cd}$ \\
P2 (Gelatin 10\%) & 0,17 & $\mathrm{de}$ \\
P1 (Gelatin 5\%) & 0,12 & \\
\hline BNT 0,05 =0,0707 & & \\
\hline
\end{tabular}

Keterangan : Huruf yang sama artinya tidak berbeda nyata pada uji BNT 5\%

Menurut Nurismanto et al. (2015), meningkatnya kadar abu permen jelly sari brokoli dipengaruhi oleh banyaknya jumlah gelatin yang ditambahkan. Penambahan konsentrasi gelatin $15 \%$ menghasilkan kadar abu $0,66 \%$, sedangkan pada konsentrasi gelatin $12 \%$ dihasilkan kadar abu $0,56 \%$. Menurut Eletra et al. (2013), penambahan konsentrasi gelatin $10 \%$ pada produk permen jelly susu kambing menghasilkan kadar abu 1,59\%.

\section{Perlakuan Terbaik (Penentuan)}

Perlakuan terbaik ditetapkan dari hasil uji sensori (flavor, kekenyalan, warna, dan penerimaan keseluruhan) dan uji kimia (kadar air dan kadar abu). Karakteristik permen jelly jamur tiram putih yang baik adalah permen jelly dengan flavor, tekstur, warna yang normal, dengan kadar air dan kadar abu sesuai SNI permen jelly 3547.22008. Data uji sensori dan kimia permen jelly jamur tiram putih disajikan pada Tabel 7.

Tabel 7. Uji sensori dan uji kimia permen jelly jamur tiram putih hasil rekapitulasi

\begin{tabular}{|c|c|c|c|c|c|c|}
\hline \multirow[t]{2}{*}{ Parameter } & \multicolumn{6}{|c|}{ Perlakuan } \\
\hline & P1 & P2 & P3 & P4 & P5 & P6 \\
\hline Flavor & $3,18 \mathrm{a} *$ & $3,10 \mathrm{ab} *$ & $2,99 b$ & $2,98 b c$ & $2,94 \mathrm{c}$ & $2,89 \mathrm{c}$ \\
\hline Kekenyalan & $2,97 \mathrm{e}$ & $3,50 \mathrm{~cd}$ & $3,77 b c$ & $3,89 \mathrm{ab} *$ & $3,99 a^{*}$ & $4,12 a^{*}$ \\
\hline Warna & $3,19 \mathrm{~d}$ & $3,43 b c$ & $3,54 \mathrm{ab} *$ & $3,71 \mathrm{a}^{*}$ & $3,56 a^{*}$ & $3,44 b$ \\
\hline $\begin{array}{l}\text { Penerimaan } \\
\text { Keseluruhan }\end{array}$ & $2,83 \mathrm{~d}$ & $3,48 b$ & $3,61 \mathrm{ab} *$ & $3,83 a^{*}$ & $3,47 b$ & $3,39 b c$ \\
\hline $\begin{array}{l}\text { Kadar air } \\
(\% \text { bb })\end{array}$ & $11,76 \mathrm{f} * *$ & $14,48 \mathrm{e}^{* *}$ & $16,28 d^{* *}$ & $18,27 \mathrm{c} * *$ & $21,90 \mathrm{~b}$ & $24,35 \mathrm{a}$ \\
\hline $\begin{array}{l}\text { Kadar abu } \\
(\% \text { bb })\end{array}$ & $0,12 \mathrm{e}^{* *}$ & $0,17 \mathrm{de}^{* *}$ & $0,21 \mathrm{~cd}^{* *}$ & $0,25 c^{* *}$ & $0,35 b^{* *}$ & $0,47 a^{* *}$ \\
\hline$\sum(*)$ & 1 & 1 & 2 & 3 & 2 & 1 \\
\hline
\end{tabular}

Keterangan :

P1 : Konsentrasi gelatin 5\%

$\mathrm{P} 2$ : Konsentrasi gelatin $10 \%$

P3 : Konsentrasi gelatin 15\%

P4 : Konsentrasi gelatin 20\%

P5 : Konsentrasi gelatin $25 \%$

P6 : Konsentrasi gelatin $30 \%$

*. : Tidak berbeda nyata pada taraf $5 \%$

** : Sesuai SNI permen jelly 3547.2-2008

Berdasarkan Tabel 7, perlakuan terbaik adalah permen jelly jamur tiram putih dengan konsentrasi gelatin sebesar $20 \%$ (P4), terlihat dari jumlah terbanyak tanda bintang pada perlakuan gelatin $20 \%$. 
Konsentrasi gelatin $20 \%$ pada permen jelly tersebut memberikan tekstur kenyal, agak khas jamur tiram putih pada parameter flavor, disuka pada warna, disuka pada penerimaan keseluruhan, dan syarat SNI permen jelly (SNI 3547.2-2008) yaitu kadar air dan kadar abu terpenuhi.

\section{Perlakuan Terbaik (Komposisi Kimia)}

Permen jelly terbaik konsentrasi gelatin 20\% dianalisis kadar gula reduksi dan kadar sukrosanya (Tabel 8).

Tabel 8. Permen jelly jamur tiram putih terbaik

\begin{tabular}{llc}
\hline Komponen & Jumlah & SNI Permen Jelly \\
\hline Gula reduksi (\%) & $0,28^{* *}$ & Maks. 25 \\
Sukrosa (\%) & $51,33^{* *}$ & Min. 27 \\
\hline
\end{tabular}

Keterangan :

** : Sesuai SNI permen jelly 3547.2-2008

Berdasarkan Tabel 8, kadar gula reduksi permen jelly jamur tiram putih terbaik sebesar 0,28\% telah memenuhi SNI permen jelly dengan kadar gula reduksi maksimal 25\%, sedangkan kadar sukrosa permen jelly jamur tiram putih sebesar $51,33 \%$ telah memenuhi SNI permen jelly dengan kadar sukrosa minimal 27\%. Kadar gula reduksi dan kadar sukrosa permen jelly jamur tiram putih telah memenuhi syarat mutu permen jelly SNI 3547.2-2008.

\section{KESIMPULAN}

Konsentrasi gelatin 20\% terbaik diperoleh pada $20 \%$ dengan produk premen jelly yang memiliki flavor agak khas jamur tiram putih dengan skor 2,98, tekstur kenyal skor 3,89, warna disukai skor 3,71, penerimaan keseluruhan disukai skor 3,83. Berdasarkan SNI, permen jelly memenuhi standar yaitu kadar air sebesar 18,27\% (bb), kadar abu 0,25\% (bb), gula reduksi 0,28\% (bb), dan kadar sukrosa 51,33\% (bb).

\section{DAFTAR PUSTAKA}

Alexs, M. ( 2011). Untung Besar Budi Daya Aneka Jamur. Pustaka Baru Press. Yogyakarta.
AOAC. (2012). Official Methods of Analysis of AOAC International. $19^{\text {th }}$ ed. USA.

Binsi, P.K., B.A. Shamasundar, A.O. Dileep, F. Badii, dan N.K.Howell. (2009). Rheological and Functional Properties of Gelatin From the Skin of Bigeye Snapper (Priacanthus hamrur) fish : Influence of Gelatin on the GelForming Ability of Fish Mince. Food Hydrocolloids. 23(1), 132145. https://doi.org/10.1016/j.foodhyd.20 07.12.004.

BeMiller, J.N. dan R.L. Whistler. (2017). Carbohydrates. In : Damodaran, S. and K.L. Parkin (ed). Fennema's Food Chemistry. Fith Edition. CRC Press. Boca Raton.

Darwin, A. Ridhay, dan J. Hardi. (2018). Kajian ekstraksi gelatin dari tulang ikan mujair (Oreochromis mossambicus). KOVALEN. 4(1), 115. e-ISSN: $2477-5398$.

Eletra, Y., Susilawati, dan S. Astuti. (2013). Pengaruh Konsentrasi Gelatin terhadap Sifat Organoleptik Permen Jelly Susu Kambing. Jurnal Teknologi Hasil Pertanian dan Industri. $\quad$ 18(2), $\quad 8-1$. 
http://dx.doi.org/10.23960/jtihp.v18i $2.185 \% 20-\% 20195$

Funami, T. (2011). Next Target for Food Hydrocolloid Studies Texture Design of Foods using Hydrocolloid Technology. Food Hydrocolloids. 25, 1904-1914.

Gotthoffer, N.R. (2012). Gelatin in Nutrition and Medicine. Great Lakes Gelatin Company.

Hamed, I., F. Ozogul, dan J.M. Regenstein. (2016). Industrial Applications of Crustacean By- Products (Chitin, Chitosan, and Chitooligosaccharides) : A Review. Trends in Food Science \& Technology. 48, 40-50. https://doi.org/10.1016/j.tifs.2015.1 1.007

Herawati, H. (2018). Potensi Hidrokoloid sebagai Bahan Tambahan pada Produk Pangan dan Nonpangan Bermutu. Jurnal Litbang Pertanian. $37(1), 17-25$. DOI:10.21082/jp3.v37n1.2018.p1725

Karim A.A. dan R. Bhat. (2008). Gelatin Alternatives for the Food Industry: Recent Developments, Challenges and Prospects. Trends in Food Science \& Technology. 19(22), 644656.

https://doi.org/10.1016/j.tifs.2008.08 .001 .

Khiari, Z., D. Rico, A.B. Martin-Diana, dan C. Barry-Ryan. (2013). Comparison between Gelatins Extracted from Mackerel and Blue Whiting Bones after Different Pre-Treatments. Food Chemistry. 139 (Issues 1-4), 347-354.

https://doi.org/10.1016/j.foodchem.2 013.01.017
Leward, D.A., S.E. Hill, dan J.R. Mitchell. (2000). Functional of Food Macromolecules. Aspen Publisher. Inc. United Kingdom.

Liu, H.Y., J. Han, dan S.D. Guo. (2009). Characteristics of the Gelatin Extracted from Channel Catfish (Ictalurus punctatus) Head Bones. Food Science \& Technology. 42(2), 540-544. https://doi.org/10.1016/j.lwt.2008.07 .013 .

Mariod, A.A dan H.F. Adam. (2013). Review : Gelatin, Source, Extraction and Industrial Applications. Acta Sci. Pol., Technol. Aliment. 12(2), 135-147.

Nelwan, B. (2015). Pengaruh Konsentrasi Gelatin dan Sirup Glukosa terhadap Sifat Kimia dan Sensoris Permen Jelly Sari Buah Pala (Myristica fragrans houtt). Jurnal Ilmu dan Teknologi Pangan. 6(3).

Nurismanto, R., Sudaryati dan A.H. Ihsan. (2015). Konsentrasi Gelatin dan Karagenan pada Pembuatan Permen Jelly Sari Brokoli (Brassica oleracea). J. Rekapangan. 9(2), 1-5.

Nguyen, P.T.M., O. Kravchuk, B. Bhandari, dan S. Prakash. (2017). Effect of Different Hydrocolloids on Texture, Rheology, Tribology and Sensory Perception of Texture and Mouthfeel of Low-Fat Pot-Set Yoghurt. Food Hydrocolloids. 72, 90-104. DOI : 10.1016/j.foodhyd. 2017.05.035.

Piccone, P., S.L. Rastelli, and P. Pittia. (2011). Aroma Release and Sensory Perception of Fruit Candies Model Systems. Procedia Food Science.

Rahmi, S.L., F. Tafzi, dan S. Anggraini. (2012). Pengaruh Penambahan Gelatin terhadap Pembuatan Permen 
Jelly dari Bunga Rosella (Hibiscus sabdariffa Linn). Jurnal Penelitian Universitas Jambi Seri Sains. 14(1), 37-44.

Setyaningsih, D., A. Apriyanto, dan M. Puspita. (2010). Analisis Sensori untuk Industri Pangan dan Agro. Institut Pertanian Bogor Press. Bogor.

Sriyono, L. Kurniawati, dan A. Mustofa. (2017). Karakteristik Permen Jelly Wortel (Daucus Carota L.) dalam Berbagai Konsentrasi Gelatin. Jurnal Teknologi dan Industri Pangan 1(1), 14-17. DOI 10.33061/JITIPARI.V1I1.1510.
Standar Nasional Indonesia. (2008). Standar Nasional Indonesia Kembang Gula. SNI 3547.2-2008. Badan Standarisasi Nasional. Indonesia.

Taufik M. (2011). Kajian Potensi Kulit Kaki Ayam Broiler sebagai Bahan Baku Gelatin dan Aplikasinya dalam Edible Film Antibakteri. Disertasi. Fakultas Peternakan Universitas Gadjah Mada, Yogyakarta.

Zuhra, C. F. (2006). Flavor (Citarasa). Departemen Kimia, Fakultas Matematika dan Ilmu Pengetahuan Alam. Universitas Sumatera Utara. 